Article

\title{
Driving Forces of Air Pollution in Ulaanbaatar City Between 2005 and 2015: An Index Decomposition Analysis
}

\author{
Enkhjargal Enkhbat ${ }^{1}$, Yong Geng ${ }^{1,2,3,4, *}$, Xi Zhang ${ }^{1}$, Huijuan Jiang ${ }^{5}{ }^{\oplus}$, Jingyu Liu ${ }^{1}$ \\ and Dong $\mathrm{Wu}^{1}$ \\ 1 School of Environmental Science and Engineering, Shanghai Jiao Tong University, Shanghai 200240, China; \\ enkhjargal@sjtu.edu.cn (E.E.); zhangxi9206@sjtu.edu.cn (X.Z.); liu.jingyu@sjtu.edu.cn (J.L.); \\ wudong9207@sjtu.edu.cn (D.W.) \\ 2 School of International and Public Affairs, Shanghai Jiao Tong University, Shanghai 200030, China \\ 3 China Institute for Urban Governance, Shanghai Jiao Tong University, Shanghai 200240, China \\ 4 Shanghai Institute of Pollution Control and Ecological Security, Shanghai 200092, China \\ 5 China-UK Low Carbon College, Shanghai Jiao Tong University, Shanghai 201306, China; \\ jianghuijuan@sjtu.edu.cn \\ * Correspondence: ygeng@sjtu.edu.cn
}

Received: 9 February 2020; Accepted: 13 April 2020; Published: 15 April 2020

\begin{abstract}
Ulaanbaatar, the capital city of Mongolia, is facing serious air pollution challengesespecially during the cold and long winter months-mainly due to fossil fuel combustion. This study investigates the socioeconomic drivers of the sulfur dioxide $\left(\mathrm{SO}_{2}\right)$, nitrogen dioxide $\left(\mathrm{NO}_{2}\right)$, and particulate matter $\left(\mathrm{PM}_{2.5}\right)$ concentration changes in Ulaanbaatar between 2005 and 2015 by applying the index decomposition analysis (IDA) method. Five socio-economic driving forces are considered in the decomposition analysis. All the driving forces contributed to more air pollution concentration changes in 2015 than in 2005, despite the decreasing trends of decomposition results for the period of 2010-2015. In general, economic growth, pollution intensity, and energy intensity significantly contributed to the changes of air pollutant concentrations, while energy structure and population growth had marginal effects. Finally, appropriate policy recommendations are proposed to the local government so that they can initiate feasible policies to effectively reduce air pollution, protect human health, and respond to climate change in Ulaanbaatar.
\end{abstract}

Keywords: air pollutants; driving forces; index decomposition analysis; $\mathrm{SO}_{2} ; \mathrm{NO}_{2} ; \mathrm{PM}_{2.5} ;$ Ulaanbaatar city; governance

\section{Introduction}

Migration to Ulaanbaatar, the capital city of Mongolia, has increased the population by $55 \%$ over the past fifteen years. Now, it is estimated that 1.4 million residents are living in Ulaanbaatar [1]. With its increasing population, this city has experienced rapid economic growth [2]. In particular, this city relies on fossil fuels (see Appendix A, Figures A1 and A2) to achieve its gross domestic product (GDP) growth and to support its rapid urbanization, leading to concerns of both air quality deterioration and climate change. Located in the dry North Asia, Ulaanbaatar has a very cold winter, with the minimum temperature below $-35^{\circ} \mathrm{C}$ in January [3]. The heating season lasts seven months, from mid-October to mid-May [4]. Unfortunately, Ulaanbaatar has very limited access to petroleum or natural gas and has to rely on coal for both power generation and heat supply due to its abundant coal reserve. Over 790,000 people reside in settlements without water, sanitation, or basic infrastructure—often in traditional Mongolian felt tents, known as gers, where these people rely on wood or coal burning 
stoves for cooking and heating [5]. Furthermore, increasing public and private transport contributes to the air pollution, as the total number of vehicles increased from 75,000 in 2005 to 383,263 in 2017 [6]. In addition, three coal burning power plants provide electricity to the entire city [7]. Ulaanbaatar is nestled in a narrow valley and surrounded by mountains, which blocks the dispersion of air pollutants in winter [8]. Due to the above reasons, Ulaanbaatar is one of the cities with the highest air pollution level. The notorious air pollution has also induced serious public health concerns. Moreover, with global concerns of climate change, this city is facing more challenges on addressing this issue.

According to the World Data Atlas [9], raw coal is the major energy source in Ulaanbaatar, accounting for $93.2 \%$ of the total energy production. Such high coal consumption induced a large amount of air pollutants, including $\mathrm{SO}_{2}, \mathrm{NO}_{2}$, and $\mathrm{PM}_{2.5}$. The total concentrations of these air pollutants far outreached the guideline values provided by the World Health Organization [10]. Figure 1 shows Ulaanbaatar's air pollutant concentrations of $\mathrm{SO}_{2}, \mathrm{NO}_{2}$, and $\mathrm{PM}_{2.5}$ in 2015. In Ulaanbaatar, the Ministry of Environment and Tourism operates 12 air pollution monitoring stations in total. Of the 12 stations, two stations measure the level of concentrations of $\mathrm{PM}_{2.5}$ using tapered element oscillating microbalances. Other stations measure the levels of concentrations of $\mathrm{SO}_{2}$ using pararosaniline (spectrophotometer) and $\mathrm{NO}_{2}$ using the Saltzman measure, respectively [11]. Among these pollutants, $\mathrm{PM}_{2.5}$ is the pollutant with the highest risk for public health and may influence the national economy [12]. According to one World Bank study [13], the annual mortality rate from air pollution-related diseases reached 1123 people in Ulaanbaatar in 2013. Many studies investigate the characteristics of $\mathrm{PM}_{2.5}$, including its concentrations, meteorological conditions, chemical compositions, and human health impact [14-17]. These studies were written from natural science perspectives. However, there are very few studies that concentrate on policies. For instance, an emission inventory was established to measure the household and industrial source effects of the major particulate $\left(\mathrm{PM}_{2.5}, \mathrm{PM}_{10}\right)$ and gaseous $\left(\mathrm{SO}_{2}, \mathrm{NO}_{2}, \mathrm{CO}\right)$ pollutants in Ulaanbaatar [12]. Therefore, additional studies using different methods, such as a combination of an emission control method and chemical transport models [18] and an economic optimization model [19] should be conducted. It is critical to focus on both natural and social perspectives, since the formation of air pollution involves complicated socio-economic activities, including public health, economic growth, energy consumption, and pollution control [20].
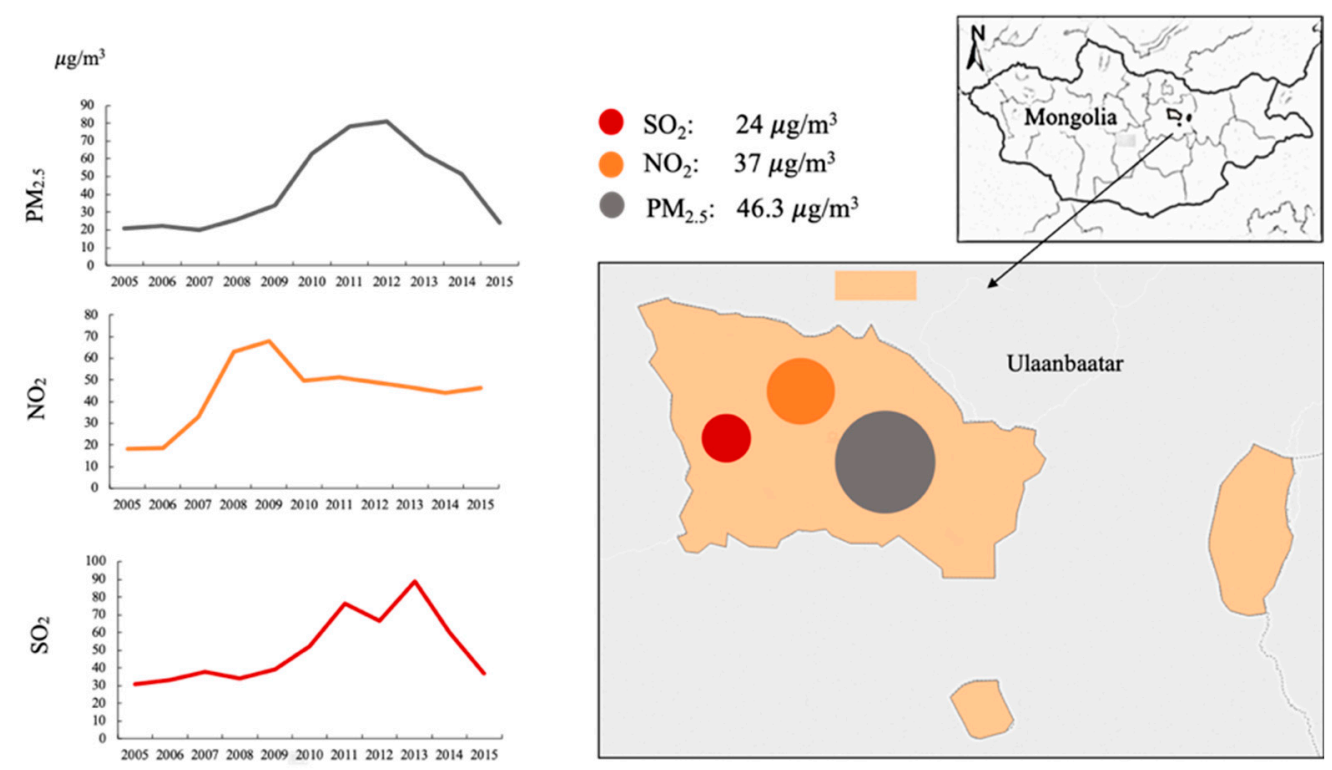

Figure 1. Air pollutant concentrations in Ulaanbaatar City in 2015 (data obtained from [21]).

Under such circumstances, the purpose of this study is to uncover the key drivers of $\mathrm{SO}_{2}, \mathrm{NO}_{2}$, and $\mathrm{PM}_{2.5}$ concentrations in Ulaanbaatar, including pollution intensity, energy structure, energy intensity, 
economic growth and population growth, by employing the Logarithmic Mean Divisa Index (LMDI) method over the period of 2005-2015. We expect that valuable recommendations can be offered to the local government so that they can prepare effective mitigation policies. We also hope that the policy implications gained from this paper can be disseminated to other cities with similar challenges. The remaining part of this paper is structured as the following: Section 2 reviews relevant literature; Section 3 details research methods and data; Section 4 presents research results; Section 5 discusses policy implications; finally, Section 6 summarizes the research conclusions.

\section{Literature Review}

Globally, there are numerous studies on the socioeconomic driving forces of different emissions, although the majority of these studies focus on carbon emissions [22-24], and on $\mathrm{PM}_{2.5}, \mathrm{SO}_{2}$, and $\mathrm{NO}_{2}$ [25-28]. In particular, several studies on the changes of $\mathrm{PM}_{2.5}$ air concentrations are studied [29,30].

Such studies can help to trace the economic, environmental, and social trends [31]. Major research methods include structural decomposition analysis (SDA) and index decomposition analysis (IDA) [32-34], which have been widely applied to analyze the impacts of economic growth, technology changes, and sectorial shifts by using different indicators [31].

By applying an input-output model to the SDA method, it decomposes relevant changes into different indicators. This method uses an additive form and a multiplicative form in order to complete the decomposition analyses [35]. One of the advantages of this method is that it takes the advantages of the sector details from the input-output tables [31]. For example, with the application of SDA, Rose and Chen [36] analyzed the changes in sectorial energy consumption in USA. Similarly, Cansino et al. [37] studied Spanish $\mathrm{CO}_{2}$ emissions from structural changes. In addition, Yamakawa and Peters [38] uncovered the key driving forces on greenhouse gas emissions in Norway by applying this method.

The IDA method can uncover the process of energy supply, energy conversion, and energy consumption so that key driving factors, such as end-use energy structure, energy mix in electricity generation, and electricity generation efficiency, can be quantitatively identified. Ang and Zhang [39] conducted a global review on this method and found that the IDA method is more suitable for analyzing energy systems, since it pays more attention to technical details. Due to this advantage, this method has been applied in analyzing energy-related carbon emissions-in particular, in the manufacturing and heavy industrial sectors [40,41]. Furthermore, several studies applied the IDA method to uncover the driving forces of air pollutant emissions and concentrations. For instance, at a national level, the main driving factors inducing changes in China's air pollutant emissions between 1997 and 2002 were investigated. The major findings of this study showed that the main drivers on inducing more $\mathrm{PM}_{2.5}, \mathrm{SO}_{2}$, and $\mathrm{NO}_{\mathrm{x}}$ were economic growth and energy intensity [28]. Another study conducted by Zhang et al. [30] focused on investigating the key drivers of $\mathrm{PM}_{2.5}$ concentrations at a municipal level so that useful policy recommendations were raised to the municipal authorities to mitigate their $\mathrm{PM}_{2.5}$ pollutions.

From the above introduction, it is clear that most existing studies focus on one specific air pollutant concentration without combining these different air pollutant concentrations together. In fact, the combustion of fossil fuels (in particular, coal) can lead to simultaneous concentrations of $\mathrm{PM}_{2.5}, \mathrm{SO}_{2}$, and $\mathrm{NO}_{\mathrm{x}}$. However, few studies focus on other pollutants than $\mathrm{PM}_{2.5}$. Therefore, it is crucial to initiate integrated studies on all three air pollutants so that more effective policies can be prepared to improve the overall air quality. With regard to Ulaanbaatar, the existing relevant studies focus on $\mathrm{PM}_{2.5}$ concentrations, chemical components, and its human health impact $[6,16,42,43]$, without examining the driving forces of air pollutants. Consequently, the literature review provides rationale to conduct this research. 


\section{Methods and Data}

\subsection{Methods}

IDA can not only identify the processes of energy supply, energy conversion, and energy consumption, but can also uncover critical driving forces, including end-use energy structure, energy mix in electricity generation, and electricity generation efficiency. Unlike IDA, SDA relies on the input-output table released by the official statistical agencies. Such a table is not available every year and its accuracy is also not reliable in many countries where statistic infrastructure is still weak and data are not accountable. On the contrary, IDA only uses aggregated sector information and has the advantage of a reduced data requirement and a simpler presentation of results. LMDI is one of the most widely used IDA methods [44,45]. This method is path-independent and provides a perfect decomposition, which can resolve the problem of remaining unexplained residual terms in the decomposition results [45]. Moreover, this method can solve zero-value problems [46]. Owing to these reasons, this paper applies the LMDI method in order to investigate the driving forces of air pollutants in Ulaanbaatar City.

According to Ang [33], $V$ is an energy or environmentally-related aggregate. Assuming that there are $n$ factors driving the changes in $V$ over time, each factor is associated with a quantitative variable, whereby there are $n$ variables, including $X_{1}, X_{2} \ldots X_{n}$. Let subscript $i$ be a sub-category of the aggregate, and $V_{i}$ expressed as the product of $X_{1, i}, X_{2, i}, \ldots$ and $X_{n, i}$. Therefore, the general IDA identity is shown in Equation (1):

$$
\mathrm{V}=\sum \mathrm{V}_{\mathrm{i}}=\sum_{\mathrm{i}} \mathrm{x}_{1, \mathrm{i}} \mathrm{x}_{2, \mathrm{i}} \ldots \mathrm{x}_{\mathrm{n}, \mathrm{i}}
$$

The difference of the aggregate during the period 0 to $T$ can be further decomposed, as shown in Equation (2):

$$
\Delta \mathrm{V}_{\text {tot }}=\mathrm{V}^{\mathrm{T}}-\mathrm{V}^{0}=\Delta \mathrm{V}_{x 1}+\Delta \mathrm{V}_{x 2}+\ldots+\Delta \mathrm{V}_{\mathrm{xn}}
$$

The sum of absolute change driven by each variable should be equal to the total absolute change of the aggregate. The term on the right side of Equation (2) is the effect associated with the respective factors in Equation (1).

Five key driving forces are investigated for uncovering the $\mathrm{SO}_{2}, \mathrm{NO}_{2}$, and $\mathrm{PM}_{2.5}$ concentration changes in this study, including pollution intensity, energy structure, energy intensity, economic growth, and population growth. The change in each factor helps to quantify all three air pollutant concentration changes from fossil fuels. The IDA identity in Equation (1) can be rewritten as Equation (3):

$$
C_{i}=C_{i} / F \times F / E \times E / G D P \times G D P / P \times P=C I \times E S \times E I \times Y \times P
$$

where $C_{i}$ represents different air pollutant concentrations; $i$ refers to $\mathrm{SO}_{2}, \mathrm{NO}_{2}$, and $\mathrm{PM}_{2.5}$ concentrations, respectively; $F$ is fossil fuel consumption; $E$ represents total energy consumption; GDP represents gross domestic product (GDP); $P$ represents population growth; $C I=C / F$ represents pollution intensity; $E S=F / E$ represents energy structure; $E I=E / G D P$ represents energy intensity; $Y=G D P / P$ represents economic growth; $P$ represents population growth (see Table 1 for the definition of variables).

The additive form gives direct information about the magnitude of concentration changes by different decomposed factors. This form is adopted in this study so that the results can be calculated from different aspects. Equation (4) shows how to calculate the changes of $\mathrm{SO}_{2}, \mathrm{NO}_{2}$, or $\mathrm{PM}_{2.5}$ concentrations.

$$
\Delta C_{i}=C_{i}^{T}-C_{i}^{0}=\Delta C_{C I}+\Delta C_{E S}+\Delta C_{E I}+\Delta C_{Y}+\Delta C_{P}
$$

where $\Delta C_{i}$ represents the pollution changes of different air pollutants; $i$ represents $\mathrm{SO}_{2}, \mathrm{NO}_{2}$, or $\mathrm{PM}_{2.5}$, respectively; $\Delta C_{C I}$ represents pollution intensity effect; $\Delta C_{E S}$ represents energy structure effect; $\Delta C_{E I}$ 
represents energy intensity effect; $\Delta C_{Y}$ represents economic scale effect; $\Delta C_{P}$ represents the population scale effect.

Table 1. Definition of variables in Equation (3).

\begin{tabular}{|c|c|c|c|c|}
\hline Variable & Determinant & Unit & Description & Description and Definition \\
\hline$C I$ & $\mathrm{C} / \mathrm{F}$ & $\begin{array}{c}\mu \mathrm{g} / \mathrm{m}^{3} \text { (micrograms per } \\
\text { cubic meter)/kilotons of } \\
\text { oil equivalent (ktoe) }\end{array}$ & Pollution intensity & $\begin{array}{l}\text { measures the amount of air pollutant } \\
\text { concentrated per unit of fossil fuel }\end{array}$ \\
\hline$E S$ & $\mathrm{~F} / \mathrm{E}$ & ktoe/ktoe & Energy structure & stands for the energy structure effect \\
\hline$E I$ & E/GDP & ktoe/billion dollar & Energy intensity & $\begin{array}{l}\text { measures the energy consumption per } \\
\text { unit of GDP, representing the energy } \\
\text { intensity effect }\end{array}$ \\
\hline Y & $\mathrm{GDP} / \mathrm{P}$ & $\begin{array}{l}\text { billion dollar/thousand } \\
\text { people }\end{array}$ & Economic growth & $\begin{array}{l}\text { presents the economic growth scale; } \\
\text { for example, measures the GDP per } \\
\text { capita of } P\end{array}$ \\
\hline$P$ & $\mathrm{P}$ & thousand people & Population growth & measures the population growth \\
\hline
\end{tabular}

These five effects can be further calculated based on Equations (5)-(9), respectively:

$$
\begin{aligned}
\Delta C_{C I} & =\frac{\left(C_{i}^{T}-C_{i}^{0}\right)}{\left(\ln C_{i}^{T}-\ln C_{i}^{0}\right)} \times \ln \left(\frac{C I^{T}}{C I^{0}}\right) \\
\Delta C_{E S} & =\frac{\left(C_{i}^{T}-C_{i}^{0}\right)}{\left(\ln C_{i}^{T}-\ln C_{i}^{0}\right)} \times \ln \left(\frac{E S^{T}}{E S^{0}}\right) \\
\Delta C_{E I} & =\frac{\left(C_{i}^{T}-C_{i}^{0}\right)}{\left(\ln C_{i}^{T}-\ln C_{i}^{0}\right)} \times \ln \left(\frac{E I^{T}}{E I^{0}}\right) \\
\Delta C_{Y} & =\frac{\left(C_{i}^{T}-C_{i}^{0}\right)}{\left(\ln C_{i}^{T}-\ln C_{i}^{0}\right)} \times \ln \left(\frac{Y^{T}}{Y^{0}}\right) \\
\Delta C_{P} & =\frac{\left(C_{i}^{T}-C_{i}^{0}\right)}{\left(\ln C_{i}^{T}-\ln C_{i}^{0}\right)} \times \ln \left(\frac{P^{T}}{P^{0}}\right)
\end{aligned}
$$

The pollution intensity effect reflects the impact of the change in fossil fuels mix. The energy structure effect captures the influence of the change of fossil fuel shares in total energy consumption. The energy intensity effect denotes the effect of the change of economic dependence on energy use. The economic growth effect indicates the impact of the change of GDP per capita. The population growth effect denotes the effect of the population change living in the city. By applying this decomposition method, the total changes in $\mathrm{SO}_{2}, \mathrm{NO}_{2}$, or $\mathrm{PM}_{2.5}$ concentrations in Ulaanbaatar City can be obtained by the sum of the five effects.

\subsection{Data Collection}

Due to data accessibility, the related data between 2005 and 2015 were collected from different sources. Ulaanbaatar's primary $\mathrm{SO}_{2}, \mathrm{NO}_{2}$, and $\mathrm{PM}_{2.5}$ concentration data were gathered from the National Statistical Information Center [21]. The final energy consumption data were collected from the IEA World Energy Balances database [47]. The GDP data were collected from the World Bank national accounts data [48] and the population data were acquired from the Statistic Department of Ulaanbaatar [49]. 


\section{Results}

Using Equations (5)-(9), we calculated the contribution rates of pollution intensity, energy structure, energy intensity, economic growth, and population growth to the changes of $\mathrm{SO}_{2}, \mathrm{NO}_{2}$, and $\mathrm{PM}_{2.5}$ concentrations in Ulaanbaatar. The annual decomposition results of the air pollutant concentrations are presented in Figures 2-4. The detailed decomposition results of three air pollutant concentrations are presented in Tables A1-A4 respectively (See Appendix B, Tables A1-A4).

Figure 2 shows the decomposition results of $\mathrm{SO}_{2}$ concentration. We can see that the most important factor that contributed to the increase of $\mathrm{SO}_{2}$ concentration in most of the years during 2005-2015 was the economic growth effect. The fluctuation of the economic growth effect between 2005 and 2015 echoed Ulaanbaatar's economy. Ulaanbaatar's GDP increased from 2.2 billion dollars in 2005 to 7.5 billion dollars in 2015 based upon the 2005 prices (see Appendix A, Figure A3). Normally, economic growth can result in high energy consumption [50]. In this regard, the total energy consumption of Ulaanbaatar increased from 2960 ktoe in 2005 to 4714 ktoe in 2015, which followed this relationship. On the contrary, pollution intensity played a crucial role in reducing $\mathrm{SO}_{2}$ concentration in most of the years during 2005-2015. The pollution intensity effect of the $\mathrm{SO}_{2}$ concentration reduction increased by 6.8 times, ranging from $2.96 \mu \mathrm{g} / \mathrm{m}^{3}$ in 2005 to $23.11 \mu \mathrm{g} / \mathrm{m}^{3}$ concentration in 2015. Interestingly, the pollution intensity effect of $\mathrm{SO}_{2}$ concentration decreased from 2011 to 2015, coupled with the decrease of the economic growth effect during the same period. In 2010, the $\mathrm{SO}_{2}$ concentration level increased by $85 \%$, and this surge affected the pollution intensity effect, which grew from $6.5 \mu \mathrm{g} / \mathrm{m}^{3}$ in 2009 to $28.9 \mu \mathrm{g} / \mathrm{m}^{3}$ in 2010. In contrast, the pollution intensity effect of $\mathrm{SO}_{2}$ decreased to $-21.1 \mu \mathrm{g} / \mathrm{m}^{3}$ in 2013 due to the reduced concentration level of $\mathrm{SO}_{2}$, which was around $23 \%$ compared to the previous year. The pollution intensity of $\mathrm{SO}_{2}$ concentration was $-4.2 \mu \mathrm{g} / \mathrm{m}^{3}$ in 2014 and decreased to $-23.1 \mu \mathrm{g} / \mathrm{m}^{3}$ in 2015. As a result, the $\mathrm{SO}_{2}$ concentration level reduced by $53 \%$.

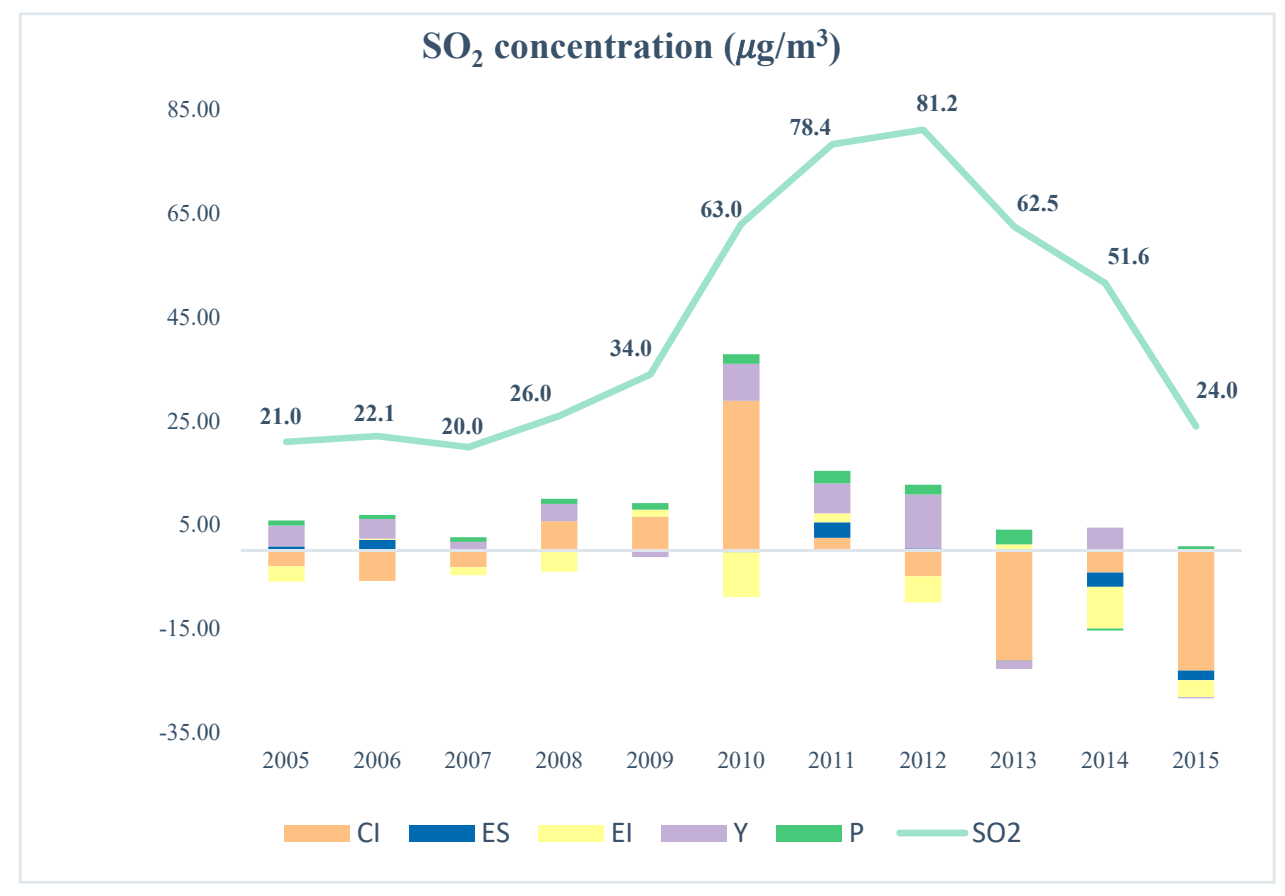

Figure 2. Annual decomposition results of $\mathrm{SO}_{2}$ concentration changes during 2005-2015.

Energy intensity was another factor on $\mathrm{SO}_{2}$ concentration reduction, from $2.98 \mu \mathrm{g} / \mathrm{m}^{3}$ in 2005 to $8.61 \mu \mathrm{g} / \mathrm{m}^{3}$ in 2015 . The other two factors (population growth and energy structure) made marginal contributions to the changes of $\mathrm{SO}_{2}$ concentration. Population growth contributed to the $\mathrm{SO}_{2}$ 
concentration increase in all years-excluding the year 2014-while energy structure led to the $\mathrm{SO}_{2}$ concentration increase in all years, excluding the years 2008, 2010, 2013, 2014, and 2015.

Figure 3 shows the additive decomposition results of $\mathrm{NO}_{2}$ concentration. The two main contributors for the $\mathrm{NO}_{2}$ concentration changes were economic growth and pollution intensity. The contribution of the economic growth effect to the $\mathrm{NO}_{2}$ concentration increase ranged from $6.10 \mu \mathrm{g} / \mathrm{m}^{3}$ in 2005 to $9.30 \mu \mathrm{g} / \mathrm{m}^{3}$ in 2012, and then decreased to $-0.35 \mu \mathrm{g} / \mathrm{m}^{3}$ in 2015. The contribution of pollution intensity increased from $-6.35 \mu \mathrm{g} / \mathrm{m}^{3}$ in 2005 to $12.87 \mu \mathrm{g} / \mathrm{m}^{3}$ in 2011, in parallel with the increase of the $\mathrm{NO}_{2}$ concentration, which grew from $31.0 \mu \mathrm{g} / \mathrm{m}^{3}$ in 2005 to $76.5 \mu \mathrm{g} / \mathrm{m}^{3}$ in 2011. Then, the pollution intensity effect fluctuated between 2012 and 2015, with significant contributions to $\mathrm{NO}_{2}$ concentration changes. Overall, the mitigating effect of pollution intensity on $\mathrm{NO}_{2}$ concentration increased from $6.35 \mu \mathrm{g} / \mathrm{m}^{3}$ in 2005 to $16.98 \mu \mathrm{g} / \mathrm{m}^{3}$ in 2015, mainly resulting from the increased use of concentration abatement technologies and low $\mathrm{NO}_{2}$ burners. These measures helped to reduce $\mathrm{NO}_{2}$ concentration by controlling the mix and proportions of fuels and air in the combustion process. Energy intensity was another important influencing factor on $\mathrm{NO}_{2}$ concentration reduction. The contribution of energy intensity to the $\mathrm{NO}_{2}$ concentration reduction fluctuated around $4.5 \mu \mathrm{g} / \mathrm{m}^{3}$ during the period of 2005-2015. In contrast, energy structure and population growth contributed to the $\mathrm{NO}_{2}$ concentration increase in most years. However, the mitigating effect from energy structure started to appear between 2013 and 2015, primarily because of the transition of energy structure to clean and renewable energy in Ulaanbaatar in recent years.

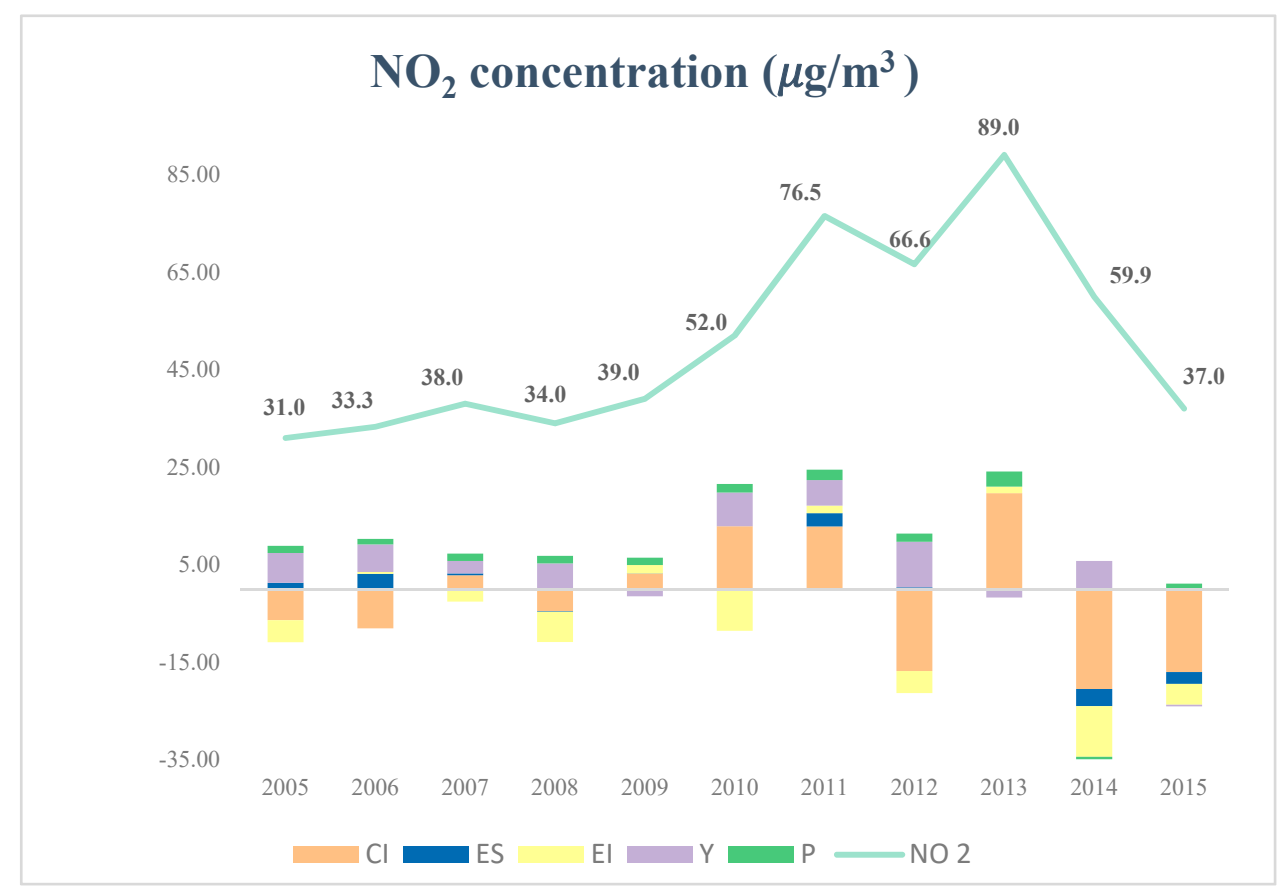

Figure 3. Annual decomposition results of $\mathrm{NO}_{2}$ concentration changes during 2005-2015.

Figure 4 shows the decomposition results of the $\mathrm{PM}_{2.5}$ concentration changes. The overall $\mathrm{PM}_{2.5}$ concentration increased by $152 \%$ during 2005-2015. Pollution intensity was the most influential factor of $\mathrm{PM}_{2.5}$ concentration in general. In 2008, it contributed to $29.34 \mu \mathrm{g} / \mathrm{m}^{3}$ of the concentration increase, which was the highest compared with those in other years. In 2009, the pollution intensity effect of $\mathrm{PM}_{2.5}$ concentration was the highest among all the driving forces. The pollution intensity of $\mathrm{PM}_{2.5}$ concentration was $2.4 \mu \mathrm{g} / \mathrm{m}^{3}$ in 2014 and increased to $8.0 \mu \mathrm{g} / \mathrm{m}^{3}$ in 2015 due to the level of $\mathrm{PM}_{2.5}$ concentration increasing by $5.3 \%$. Economic growth and energy intensity also had significant effects on $\mathrm{PM}_{2.5}$ concentration. The contribution of economic growth to $\mathrm{PM}_{2.5}$ concentration increased from 3.58 $\mu \mathrm{g} / \mathrm{m}^{3}$ in 2005 to $8.89 \mu \mathrm{g} / \mathrm{m}^{3}$ in 2010 , followed by the decrease to $-0.34 \mu \mathrm{g} / \mathrm{m}^{3}$ in 2015 . Energy intensity 
was the mitigating factor of $\mathrm{PM}_{2.5}$ concentration. This mitigating effect from energy intensity increased from $2.66 \mu \mathrm{g} / \mathrm{m}^{3}$ in 2005 to $10.69 \mu \mathrm{g} / \mathrm{m}^{3}$ in 2010, and then dropped to $4.06 \mu \mathrm{g} / \mathrm{m}^{3}$ in 2015. In contrast, both the population growth and energy structure effects of $\mathrm{PM}_{2.5}$ concentration were positive, although they had very marginal impacts.

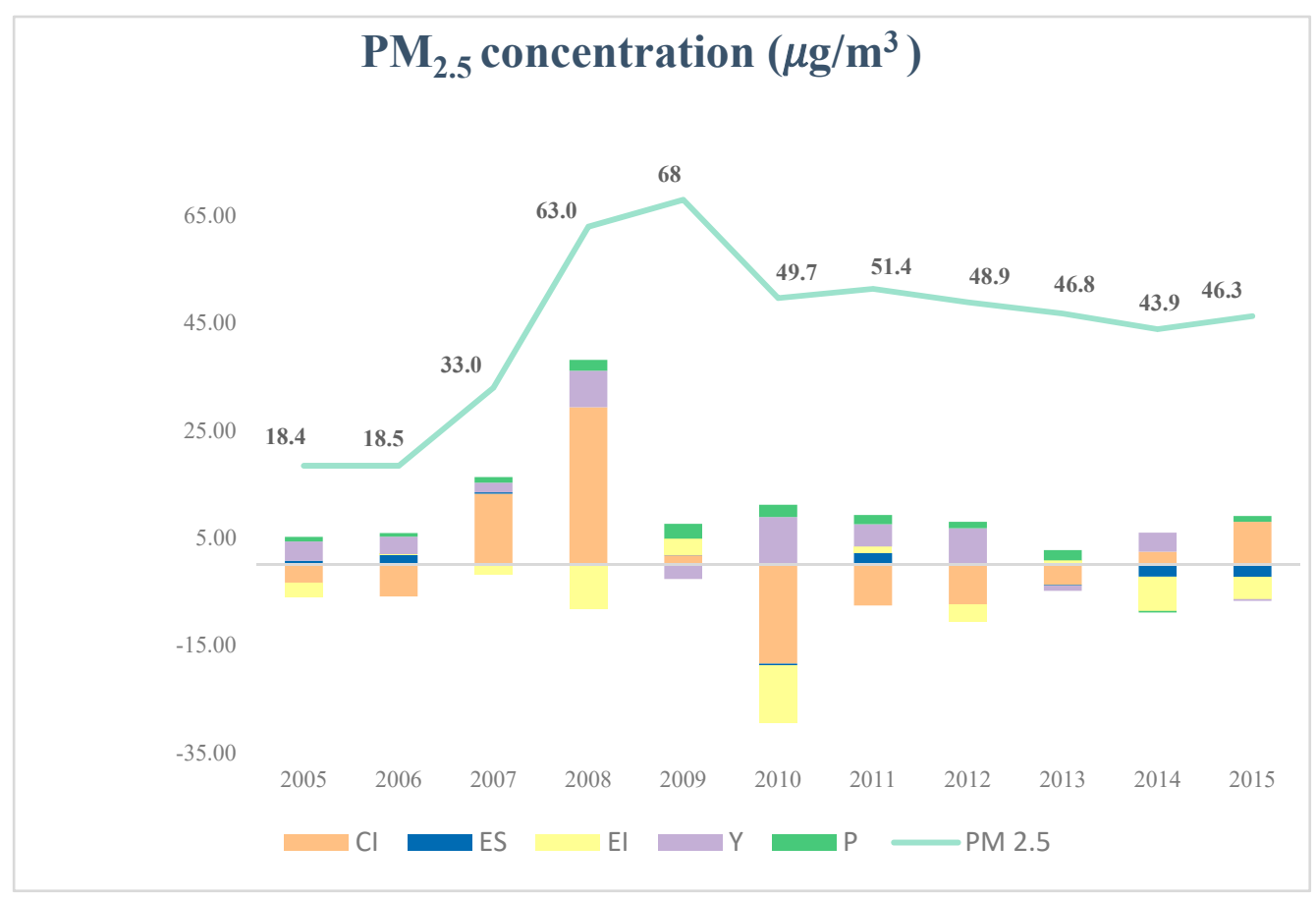

Figure 4. Annual decomposition results of $\mathrm{PM}_{2.5}$ concentration changes during 2005-2015.

To compare the effects from different driving factors on air pollution concentration changes during different time intervals, we split the entire period (2005-2015) into two sub-periods. The first sub-period started in 2005 and ended in 2010, considering that the decomposition result showed that all factors of air pollution concentration increased between 2005 and 2010. The second sub-period covered the period of 2010-2015, given the fact that all factors except the energy intensity effect decreased during these years. Figure 5 shows the decomposition results of the $\mathrm{SO}_{2}, \mathrm{NO}_{2}$, and $\mathrm{PM}_{2.5}$ concentration changes during 2005-2010 and 2010-2015. Pollution intensity contributed to the increase of $25.26 \mu \mathrm{g} / \mathrm{m}^{3}$ of $\mathrm{SO}_{2}$ concentration during 2005-2010, while it led to a decrease of $-41.94 \mu \mathrm{g} / \mathrm{m}^{3}$ of $\mathrm{SO}_{2}$ concentration during 2010-2015. Thus, pollution intensity transformed from the largest enhancing factor to the largest mitigating factor of $\mathrm{SO}_{2}$ concentration. Energy intensity was the only mitigating factor of $\mathrm{SO}_{2}$ concentration during 2005-2010, while pollution intensity, energy intensity, and energy structure jointly contributed to the $\mathrm{SO}_{2}$ concentration reduction during 2010-2015. Economic growth was the largest influential factor on the $\mathrm{SO}_{2}$ concentration increase during 2010-2015, which was surpassed by the pollution intensity effect during 2005-2010. The effect from energy structure on $\mathrm{SO}_{2}$ concentration also transformed, from being positive $3.74 \mu \mathrm{g} / \mathrm{m}^{3}$ during 2005-2010 to negative $-2.13 \mu \mathrm{g} / \mathrm{m}^{3}$ during 2010-2015. Both the effects from economic growth and population growth decreased from the first sub-period (2005-2010) to the second sub-period (2010-2015), with the decreasing rates of $45 \%$ and $40 \%$, respectively.

With regard to $\mathrm{NO}_{2}$ concentration, economic growth was the dominant driving force of the $\mathrm{NO}_{2}$ concentration increase during the two sub-periods, with contributions of $20.55 \mu \mathrm{g} / \mathrm{m}^{3}$ during 2005-2010 and $11.6 \mu \mathrm{g} / \mathrm{m}^{3}$ during 2010-2015, respectively. Population growth was the second driving force of the $\mathrm{NO}_{2}$ concentration increase, and its contribution decreased from $8.24 \mu \mathrm{g} / \mathrm{m}^{3}$ during 2005-2010 to $5.07 \mu \mathrm{g} / \mathrm{m}^{3}$ during 2010-2015. In contrast, energy intensity exerted a significant reduction effect 
on $\mathrm{NO}_{2}$ concentration during the two sub-periods, with the reduction effects of $14.98 \mu \mathrm{g} / \mathrm{m}^{3}$ during 2005-2010 and $11.15 \mu \mathrm{g} / \mathrm{m}^{3}$ during 2010-2015, respectively. The effects of pollution intensity and energy structure were much smaller during the first sub-period (2005-2010), with contributions of $3.22 \mu \mathrm{g} / \mathrm{m}^{3}$ and $3.97 \mu \mathrm{g} / \mathrm{m}^{3}$ of $\mathrm{NO}_{2}$ concentration, respectively. However, it is noteworthy that pollution intensity and energy structure turned out to be the largest and smallest mitigation factors of $\mathrm{NO}_{2}$ concentration during the second sub-period (2010-2015), respectively, which greatly contributed to the sharp reduction of $\mathrm{NO}_{2}$ concentration from $52 \mu \mathrm{g} / \mathrm{m}^{3}$ in 2010 to $37 \mu \mathrm{g} / \mathrm{m}^{3}$ in 2015 .

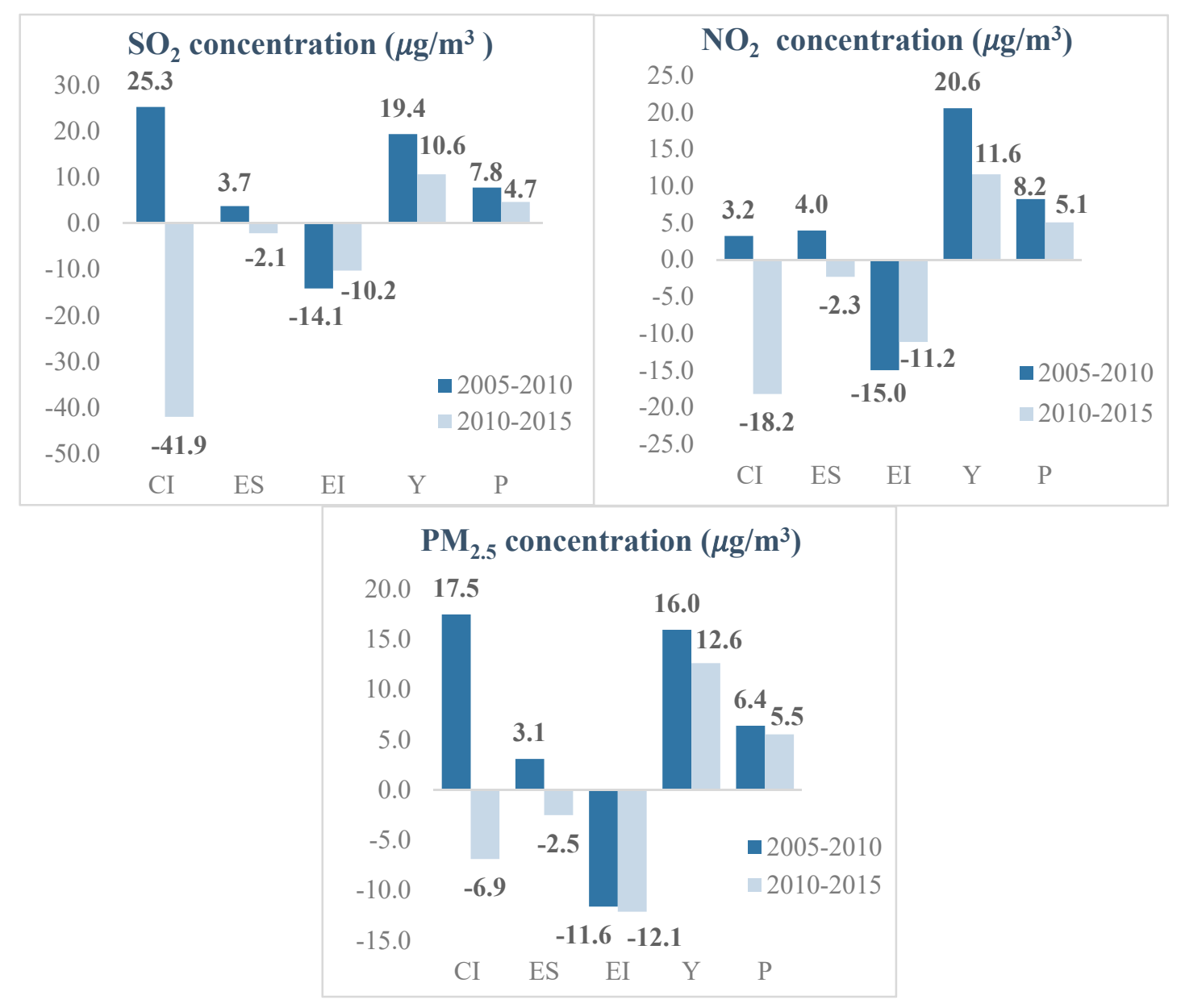

Figure 5. Decomposition results of $\mathrm{SO}_{2}, \mathrm{NO}_{2}$, and $\mathrm{PM}_{2.5}$ concentrations changes during 2005-2010 and 2010-2015.

Finally, with regard to $\mathrm{PM}_{2.5}$ concentration, pollution intensity was the dominant factor, with $17.47 \mu \mathrm{g} / \mathrm{m}^{3}$ of $\mathrm{PM}_{2.5}$ concentration growth during the first sub-period (2005-2010), followed by economic growth of $15.95 \mu \mathrm{g} / \mathrm{m}^{3}$. In contrast, population growth and energy structure had marginal contributions to the $\mathrm{PM}_{2.5}$ concentration increase during the first sub-period. Energy intensity remained the largest mitigation factor of $\mathrm{PM}_{2.5}$ concentration during the two sub-periods. The concentration-reduction effect of energy intensity had little increase, from $-11.63 \mu \mathrm{g} / \mathrm{m}^{3}$ during 2005-2010 to $-12.14 \mu \mathrm{g} / \mathrm{m}^{3}$ during 2010-2015. Pollution intensity was the second driving factor of the $\mathrm{PM}_{2.5}$ concentration reduction, while energy structure exerted the least mitigating effect on $\mathrm{PM}_{2.5}$ concentration during the second sub-period (2010-2015). On the contrary, economic growth was the largest contributor to the $\mathrm{PM}_{2.5}$ concentration increase during 2010-2015, followed by population growth. As a result, the $\mathrm{PM}_{2.5}$ concentration increased by $170 \%$ during the first sub-period and decreased by $7 \%$ during the second sub-period. $\mathrm{SO}_{2}$ and $\mathrm{PM}_{2.5}$ are pollutants that can primarily be 
associated with the types and amounts of combusted fuels. Therefore, it can be concluded that the contents of the sulfur and ash were responsible for the concentrations of $\mathrm{SO}_{2}$ and $\mathrm{PM}_{2.5}$, given the fact that fossil fuel combustion in ger districts is a major contributor to air pollution in Ulaanbaatar.

\section{Discussions}

Despite the fact that the $\mathrm{SO}_{2}, \mathrm{NO}_{2}$, and $\mathrm{PM}_{2.5}$ concentrations in Ulaanbaatar decreased during the second sub-period (2010-2015), the concentration levels remain higher than the standard level set by the World Health Organization [10]. This decrease could be associated with the actions taken by the local government's effort to subsidize electricity costs in ger districts to combat the air pollution. However, the combustion of fossil fuel remains the largest source of air pollution in the city and it can be concluded that the contents of the sulfur and ash are responsible for the concentrations of air pollutants. Hence, more efforts should be made to improve the local air quality in Ulaanbaatar.

According to the decomposition results, the effect of economic growth was the key factor for the increase of all three air pollutants in Ulaanbaatar, especially during the rapid economic boom period that happened between 2009 and 2011. While this economic growth effect played a significant role in the increase of air pollutants, pollution intensity and energy intensity had significant effects on the decreases of $\mathrm{SO}_{2}, \mathrm{NO}_{2}$, and $\mathrm{PM}_{2.5}$ concentrations in most years between 2005 and 2015.

Throughout the two sub-periods, the contributions of pollution intensity to the $\mathrm{SO}_{2}, \mathrm{NO}_{2}$, and $\mathrm{PM}_{2.5}$ concentrations fluctuated. However, its overall effect on those concentrations decreased in 2015, compared to 2005. This negative contribution was due to the increased use of electricity, leading to the pollution intensity effect on $\mathrm{PM}_{2.5}$ concentrations becoming positive in 2015 compared to its negative effect in 2005. Although the energy structure factor led to the increase in all three pollutant concentrations, these changes were not significant enough to make any differences. Interestingly, its effects on air pollutant concentrations started to decrease during 2012-2015.

Lastly, the contribution of population growth reduced for all three air pollutants in the second sub-period compared to the first sub-period. As per the data released by the Statistic Department of Ulaanbaatar [51], the number of people living in the ger districts increased between 2010 and 2018, in line with the overall population growth of Ulaanbaatar. Thus, there was no direct link between population growth in the ger districts and the population growth factor.

Sustainable urbanization requires that urban development processes should not deteriorate the local environment, while still meeting the demands of the local population [13]. According to the Green Development Strategic Action Plan, Ulaanbaatar should consider effecting the environmentally sustainable policies, which will achieve inclusive economic growth, active public participation, and a safe and healthy living environment for its citizens [52].

Developing countries often face a dilemma with their pollution control, as their efforts may undermine economic growth. It is crucial for developing countries to provide cheap electricity to support their industries and citizens. Renewable energy requires significant investment despite the low operating cost. Therefore, it is not easy to widely promote renewable energy applications in the short term due to the lack of financial resources. However, innovative mitigation policies should be prepared to reduce air pollution and protect human health, even without the wide promotion of renewable energy. For instance, district heating is one effective measure to reduce the overall air pollutants. Furthermore, the local government may set up pollution limits from a range of sources and ban or limit the used motor vehicle imports. Financial subsidies should be provided to those factories that produce semi-coke briquettes and use energy efficient stoves. Moreover, long term action plans should focus on renewable energy production. For instance, there is an opportunity to promote solar water heating systems for new housing complexes because, annually, there are 250 sunny days in this city [53].

Practically, "the 2017 Mongolia National Program" states to reduce air pollutants by $80 \%$ in 2025 [54] and calls for phasing out the practice of unprocessed coal, excluding three power plants in Ulaanbaatar. In order to achieve this target, the local government initiated several efforts. For example, in 2016, the local government offered subsidies for more efficient wood and coal burning stoves and 
provided free electricity to several ger districts during the night. Another measure was to promote the use of electrical heat generators and the application of central heating systems in the ger districts. However, such efforts were not sufficient, since only 3.6\% of total final energy consumption in this city in 2015 was based upon renewable energy sources [55]. Consequently, it is critical for the local government to actively encourage the promotion of renewable energy, such as solar power and wind power. In addition, geothermal power, such as the use of ground source heat pumps, can significantly reduce the overall use of fossil fuels and corresponding air pollutants and greenhouse gas emissions [56]. Therefore, the local government should support the potential application of such innovative technologies.

Improving coal quality while reducing coal consumption is another measure that should be further applied in Ulaanbaatar, especially for controlling energy intensity-driven concentrations. According to the World Bank study [13], coal is expected to be the primary energy source for the next 5-10 years in Ulaanbaatar. Facing such a challenge, the local government is currently promoting the use of improved coal, such as semi-coke briquettes. Also, as one measure for cleaning up this city's air quality, the local government banned the usage of raw coal in May 2019. However, the real implementation of this policy is not effective, since raw coal is cheaper and can be easily obtained by those in the ger districts. Under such a condition, the initiation of more capacity-building activities has been suggested in order to educate different stakeholders so that they can realize the potential damages to their health and local air quality. Similar efforts should also be initiated to grassroot enforcement officials so that they can better enforce related policies. Moreover, the local government should support more research and development (R\&D) activities so that more energy efficient technologies will be available, such as energy cascading technology, energy efficient stoves, and energy audits.

Finally, accurate and timely data are essential for effective air quality management. As a developing country, Mongolia is lacking advanced information and communication technologies. Local decision makers find it difficult to obtain relevant information. Thus, the local government may consider investing to build a dynamic information platform so that all the related information and data can be integrated. Such an information platform can serve as one decision support system so that different stakeholders can share the data and information. It can also be beneficial for the decision makers to identify the key areas with the application of a geographical information system (GIS) and predict the potential impacts of different policies. Besides this information platform, it is crucial for the local government to install on-site sensors in the key pollution sites (such as the ger districts and coal burning power plants) so that real data can be collected and local air quality can be monitored. In order to make sure that such an integrated system can function well, it is recommended that the local government should collaborate with the local research institutes or universities so that the whole system can be operated and maintained more effectively.

\section{Conclusions}

The serious air pollution in Ulaanbaatar receives increasing attention. The reliance on coal has further exacerbated this problem. Under such conditions, this study investigates the changes of three air pollutant concentrations (including $\mathrm{SO}_{2}, \mathrm{NO}_{2}$, and $\mathrm{PM}_{2.5}$ ) for the period of 2005-2015 in Ulaanbaatar by applying the LMDI method so that the driving forces for the changes of these air pollutant concentrations can be identified. Five socio-economic driving forces are considered in the decomposition analysis: i.e., pollution intensity, energy structure, energy intensity, economic growth, and population growth. The results showed that all the driving forces contributed to more air pollution concentration changes in 2015 than in 2005. Economic growth, pollution intensity, and energy intensity significantly contributed to the changes of air pollutant concentrations, while energy structure and population growth had marginal effects. Economic growth was the major factor that contributed to the increase of $\mathrm{SO}_{2}, \mathrm{NO}_{2}$, and $\mathrm{PM}_{2.5}$ concentrations in most years during 2005-2015, while energy intensity had a visible effect on decreasing $\mathrm{SO}_{2}, \mathrm{NO}_{2}$, and $\mathrm{PM}_{2.5}$ concentrations in most years during 2005-2015. 
The effects of pollution intensity on $\mathrm{SO}_{2}, \mathrm{NO}_{2}$, and $\mathrm{PM}_{2.5}$ concentrations were significant, but with volatile intervals of pollution increase and decrease.

The effects of all factors, excluding energy intensity, decreased during the second sub-period compared to the first sub-period. Economic growth maintained to be the largest contributor to the increase of three air pollutant concentrations in both of the two sub-periods. In contrast, the energy intensity factor was the mitigating factor during the two sub-periods. The effect of pollution intensity transformed from positive to negative on $\mathrm{SO}_{2}, \mathrm{NO}_{2}$, and $\mathrm{PM}_{2.5}$ concentrations from the first sub-period (2005-2010) to the second sub-period (2010-2015). Population growth and energy structure had relatively small effects on the three pollutants.

In order to respond to this air pollution issue, the Ulaanbaatar government has taken several measures, such as the promotion of semi-coke briquettes and subsidies to local communities for using electric stoves. However, these efforts are far from achieving their proposed target. By considering the local realities, policy recommendations, including energy structure optimization, energy efficiency improvements, and capacity-building efforts, are provided. We expect that the key findings from this study can help other cities with similar challenges to better prepare their mitigation policies by considering local realities.

Author Contributions: Conceptualization, E.E., Y.G. and X.Z.; Methodology, E.E. and X.Z.; Formal analysis, X.Z., H.J. and J.L.; Resources, E.E.; Data curation, E.E. and X.Z.; Writing-Original draft preparation, J.L., H.J. and D.W., writing -review and editing, Y.G., and X.Z. and E.E.; Supervision, Y.G.; Funding acquisition, Y.G. All authors have read and agreed to the published version of the manuscript.

Funding: This research was funded by the National Natural Science Foundation of China (Nos. 71690241, 71810107001), the Shanghai Municipal Government (17XD1401800), Yunnan Provincial Research Academy of Environmental Science, and the big data project funded by Shanghai Jiao Tong University (SJTU-2019UGBD-03).

Acknowledgments: We acknowledge the financial support from the National Natural Science Foundation of China (Nos. 71690241, 71810107001), the Shanghai Municipal Government (17XD1401800), Yunnan Provincial Research Academy of Environmental Science, and the big data project funded by Shanghai Jiao Tong University (SJTU-2019UGBD-03).

Conflicts of Interest: The authors declare no conflict of interest.

\section{Appendix A}

\section{TOTAL ENERGY CONSUMPTION}

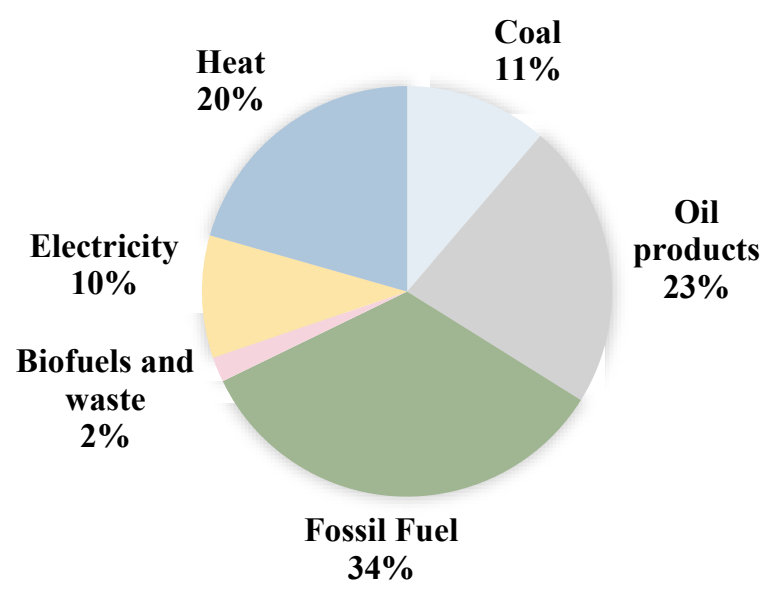

Figure A1. Total Energy Consumption by Fuel of Ulaanbaatar, Mongolia. 2015. Source: [47] 


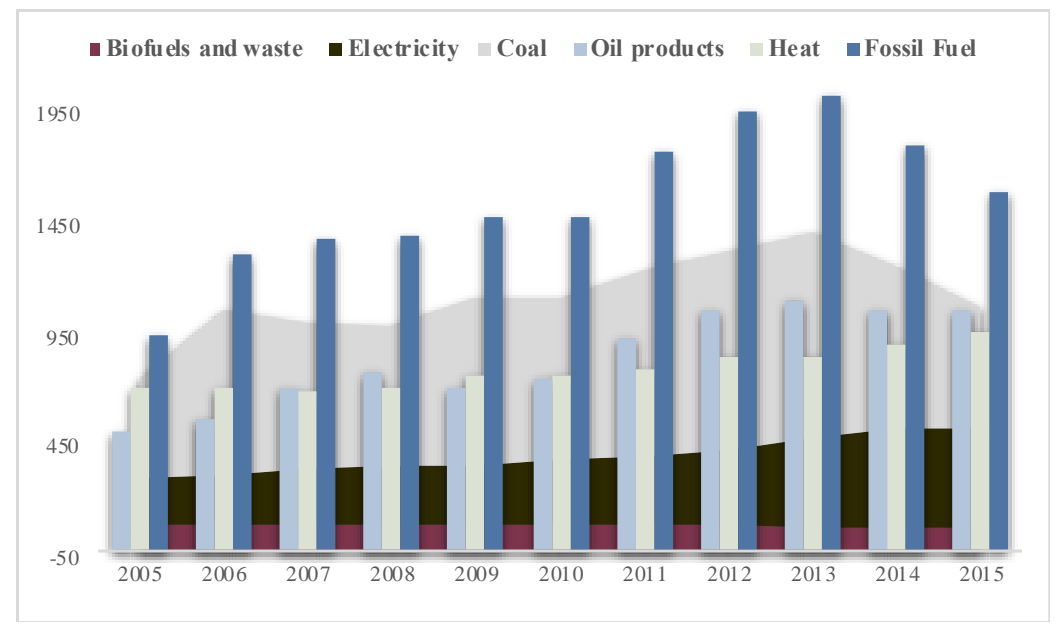

Figure A2. Total Energy Consumption by Fuel of Ulaanbaatar, Mongolia. 2005-2015. Source: [47]

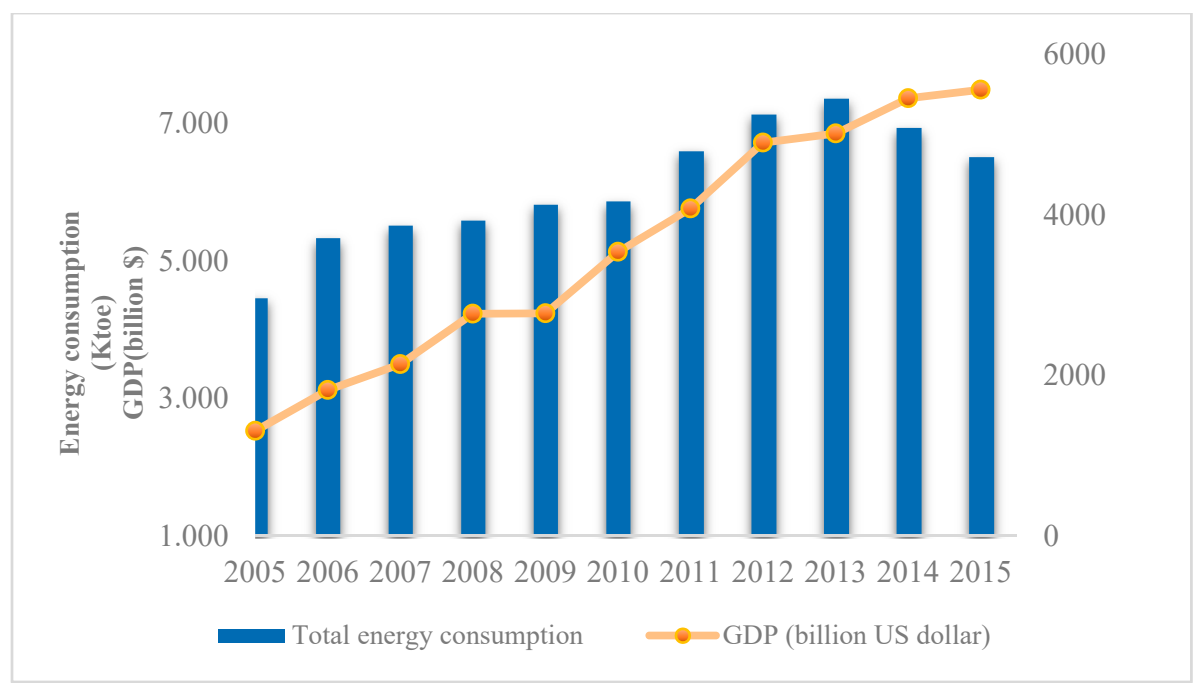

Figure A3. Energy Consumption and Total Gross Domestic Product, (US billion dollars) of Ulaanbaatar. 2005-2015. Source: [48]

\section{Appendix B}

Table A1. Time series of additive decomposition results of $\mathrm{SO}_{2}$.

\begin{tabular}{cccccc}
\hline Year & $\Delta \boldsymbol{C}_{\boldsymbol{c} i}$ & $\Delta \boldsymbol{C}_{\boldsymbol{e s}}$ & $\Delta \boldsymbol{C}_{\boldsymbol{e} i}$ & $\Delta \boldsymbol{C}_{\boldsymbol{y}}$ & $\Delta \boldsymbol{C}_{\boldsymbol{p}}$ \\
\hline 2005 & -2.96 & 0.87 & -2.98 & 4.01 & 0.96 \\
2006 & -5.82 & 2.10 & 0.25 & 3.79 & 0.78 \\
2007 & -3.19 & 0.22 & -1.52 & 1.50 & 0.89 \\
2008 & 5.67 & -0.10 & -3.92 & 3.35 & 1.00 \\
2009 & 6.54 & 0.02 & 1.39 & -1.20 & 1.25 \\
2010 & 28.90 & -0.29 & -8.61 & 7.16 & 1.84 \\
2011 & 2.49 & 3.02 & 1.72 & 5.80 & 2.37 \\
2012 & -4.91 & 0.44 & -5.03 & 10.39 & 1.90 \\
2013 & -21.20 & -0.14 & 1.23 & -1.45 & 2.86 \\
2014 & -4.21 & -2.73 & -8.05 & 4.46 & -0.38 \\
2015 & -23.11 & -1.85 & -3.25 & -0.27 & 0.87
\end{tabular}

Note: ci-pollution intensity, es-energy structure, ei-energy intensity, y-economic growth, p-population growth. 
Table A2. Time series of additive decomposition results of $\mathrm{NO}_{2}$.

\begin{tabular}{cccccc}
\hline Year & $\Delta \boldsymbol{C}_{c i}$ & $\Delta \boldsymbol{C}_{\boldsymbol{e s}}$ & $\Delta \boldsymbol{C}_{\boldsymbol{e} i}$ & $\Delta \boldsymbol{C}_{\boldsymbol{y}}$ & $\Delta \boldsymbol{C}_{\boldsymbol{p}}$ \\
\hline 2005 & -6.35 & 1.32 & -4.52 & 6.10 & 1.46 \\
2006 & -8.02 & 3.13 & 0.37 & 5.65 & 1.17 \\
2007 & 2.86 & 0.37 & -2.57 & 2.54 & 1.50 \\
2008 & -4.51 & -0.15 & -6.17 & 5.27 & 1.56 \\
2009 & 3.21 & 0.02 & 1.70 & -1.46 & 1.53 \\
2010 & 12.91 & -0.28 & -8.28 & 6.89 & 1.76 \\
2011 & 12.87 & 2.72 & 1.55 & 5.22 & 2.14 \\
2012 & -16.80 & 0.40 & -4.50 & 9.30 & 1.70 \\
2013 & 19.70 & -0.15 & 1.33 & -1.57 & 3.10 \\
2014 & -20.45 & -3.53 & -10.40 & 5.77 & -0.49 \\
2015 & -16.98 & -2.43 & -4.28 & -0.35 & 1.15 \\
\hline
\end{tabular}

Table A3. Time series of additive decomposition results of $\mathrm{PM}_{2.5}$.

\begin{tabular}{cccccc}
\hline Year & $\Delta C_{c i}$ & $\Delta C_{e s}$ & $\Delta C_{e i}$ & $\Delta C_{y}$ & $\Delta C_{p}$ \\
\hline 2005 & -3.30 & 0.77 & -2.66 & 3.58 & 0.86 \\
2006 & -5.89 & 1.79 & 0.21 & 3.24 & 0.67 \\
2007 & 13.26 & 0.26 & -1.81 & 1.79 & 1.05 \\
2008 & 29.34 & -0.20 & -7.96 & 6.80 & 2.02 \\
2009 & 1.79 & 0.04 & 3.05 & -2.63 & 2.74 \\
2010 & -18.42 & -0.36 & -10.69 & 8.89 & 2.28 \\
2011 & -7.57 & 2.17 & 1.23 & 4.16 & 1.70 \\
2012 & -7.34 & 0.28 & -3.16 & 6.53 & 1.19 \\
2013 & -3.77 & -0.09 & 0.82 & -0.97 & 1.92 \\
2014 & 2.43 & -2.18 & -6.41 & 3.56 & -0.30 \\
2015 & 8.02 & -2.31 & -4.06 & -0.34 & 1.09 \\
\hline
\end{tabular}

Table A4. Two periods of additive decomposition results of $\mathrm{SO}_{2}, \mathrm{NO}_{2}$, and $\mathrm{PM}_{2.5}$.

\begin{tabular}{ccccccc}
\hline \multirow{2}{*}{ Year } & \multicolumn{2}{c}{$\mathbf{S O}_{\mathbf{2}}$} & \multicolumn{2}{c}{$\mathbf{N O}_{\mathbf{2}}$} & \multicolumn{2}{c}{$\mathbf{P M}_{\mathbf{2 . 5}}$} \\
\cline { 2 - 7 } & $\mathbf{2 0 0 5 - 2 0 1 0}$ & $\mathbf{2 0 1 0 - 2 0 1 5}$ & $\mathbf{2 0 0 5 - 2 0 1 0}$ & $\mathbf{2 0 1 0 - 2 0 1 5}$ & $\mathbf{2 0 0 5 - 2 0 1 0}$ & $\mathbf{2 0 1 0 - 2 0 1 5}$ \\
\hline CI & 25.26 & -41.94 & 3.22 & -18.20 & 17.47 & -6.89 \\
\hline ES & 3.74 & -2.13 & 3.97 & -2.32 & 3.08 & -2.52 \\
\hline EI & -14.11 & -10.22 & -14.98 & -11.15 & -11.63 & -12.14 \\
\hline Y & 19.35 & 10.63 & 20.55 & 11.60 & 15.95 & 12.62 \\
\hline $\mathbf{P}$ & 7.76 & 4.65 & 8.236 & 5.074 & 6.39 & 5.52 \\
\hline
\end{tabular}

\section{References}

1. World Bank. Better Air Quality in Ulaanbaatar Begins in Ger Areas. 2018. Available online: https://www. worldbank.org/en/news/feature/2018/06/26/better-air-quality-in-ulaanbaatar-begins-in-ger-areas (accessed on 12 March 2020).

2. Byamba, B.; Ishikawa, M. Municipal solid waste management in Ulaanbaatar, Mongolia: Systems analysis. Sustainability 2017, 9, 896. [CrossRef]

3. World Weather Online. Ulaanbaatar Weather Averages. 2016. Available online: https://www. worldweatheronline.com/ulaanbaatar-weather-averages/ulaanbaatar/mn.aspx (accessed on 8 April 2019).

4. World Bank. Ulaanbaatar's Air Pollution Crisis: Summertime Complacency Won't Solve the Wintertime Problem. 2010. Available online: https://blogs.worldbank.org/eastasiapacific/ulaanbaatar-s-air-pollutioncrisis-summertime-complacency-won-t-solve-the-wintertime-problem (accessed on 19 March 2020).

5. World Bank. Mongolia's Growing Shantytowns: The Cold and Toxic Ger Districts. 2009. Available online: https://blogs.worldbank.org/eastasiapacific/mongolias-growing-shantytowns-the-cold-and-toxicger-districts (accessed on 11 March 2020). 
6. Amarsaikhan, D.; Battsengel, V.; Nergui, B.; Ganzorig, M.; Bolor, G. A study on air pollution in Ulaanbaatar City, Mongolia. GEP 2014, 2, 123-128. [CrossRef]

7. Davy, P.K.; Guchin, G.; Markwitz, A. Air particulate matter pollution in Ulaanbaatar, Mongolia: Determination of composition, source contributions and source locations. Atmos. Pollut. Res. 2011, 2, 126-137. [CrossRef]

8. National Geographic. Kids Suffer Most in One of Earth's Most Polluted Cities. 2019. Available online: https://www.nationalgeographic.com/environment/2019/03/mongolia-air-pollution/ (accessed on 12 March 2020).

9. World Data Atlas. Mongolia- Fossil Fuel Energy Consumption as a Share of Total Energy Consumption. 2004. Available online: https://knoema.com/atlas/Mongolia/Fossil-fuel-energy-consumption (accessed on 1 December 2019).

10. World Health Organization (WHO). Air Quality Guidelines- Global Update. 2005. Available online: https://www.who.int (accessed on 3 December 2019).

11. Franklin, M.; Chau, K.; Kalashnikova, V.O.; Garay, J.M.; Enebish, T.; Sorek-Hamer, M. Using multi-angle imaging spectroradiometer aerosol mixture properties for air quality assessment in Mongolia. Remote Sens. 2018, 10, 1317. [CrossRef]

12. Guttikunda, S.; Lodoisamba, S.; Bulgansaikhan, B.; Dashdondog, B. Particulate Pollution in Ulaanbaatar, Mongolia. Air Qual. Atmos. Health 2013, 6, 589-601. [CrossRef]

13. World Bank, Development Research Center of the State Council. Urban China: Toward Efficient, Inclusive, and Sustainable Urbanization. 2014. Available online: https://www.worldbank.org/en/country/china/ publication/urban-china-toward-efficient-inclusive-sustainable-urbanization (accessed on 15 October 2019).

14. Guttikunda, S. Urban Air Pollution Analysis for Ulaanbaatar. The World Bank. 2017. Available online: http: //documents.worldbank.org/curated/en/900891468276852126/pdf/660820v10revis00Mongolia0Report0Web. pdf (accessed on 23 May 2019).

15. Hauck, M. Epiphytic lichens indicate recent increase in air pollution in the Mongolian capital Ulan Bator. Lichenologist 2008, 40, 165-168. [CrossRef]

16. Nishikawa, M.; Matsui, I.; Batdorj, D.; Jugder, D.; Mori, I.; Shimizu, A.; Sugimoto, N.; Takahashi, K. Chemical composition of urban airborne particulate matter in Ulaanbaatar. Atmos. Environ. 2011, 45, 5710-5715. [CrossRef]

17. Nishikawa, M.; Matsui, I.; Mori, I.; Batdorj, D.; Sarangerel, E.; Onishi, K.; Shimizu, A.; Sugimoto, N. Chemical characteristics of airborne particulate matter during the winter season in Ulaanbaatar. Earozoru Kenyu 2015, 30, 126-133. [CrossRef]

18. Zhu, S.; Horne, J.; Mac Kinnon, M.; Samuelsen, G.; Dabdub, D. Comprehensively assessing the drivers of future air quality in California. Environ. Int. 2019, 125, 386-398. [CrossRef]

19. Mac Kinnon, M.; Zhu, S.; Carreras-Sospedra, M.; Soukup, J.V.; Dabdub, D.; Samuelsen, G.S.; Brouwer, J. Considering future regional air quality impacts of the transportation sector. Energy Policy 2019, 124, 63-80. [CrossRef]

20. Ji, X.; Yao, Y.; Long, X. What causes $\mathrm{PM}_{2.5}$ pollution? Cross-economy empirical analysis from socioeconomic perspective. Energy Policy 2018, 119, 458-472. [CrossRef]

21. National Statistical Information Service, Ulaanbaatar, Mongolia. Average Concentration of Air Pollution by Station. Available online: http://www.1212.mn/tables.aspx?tbl_id=DT_NSO_2400_015V2\&IND_AIR_select_ all=0\&IND_AIRSingleSelect=\&IND_AIR1_select_all=0\&IND_AIR1SingleSelect=_19\&YearM_select_all= 0\&YearMSingleSelect=_201909\&viewtype $=($ accessed on 14 March 2020).

22. Zhang, M.; Mu, H.; Ning, Y.; Song, Y. Decomposition of energy-related $\mathrm{CO}_{2}$ emission over 1991-2006 in China. Ecol. Econ. 2009, 68, 2122-2128. [CrossRef]

23. Andreoni, V.; Galmarini, S. Decoupling economic growth from carbon dioxide emissions: A decomposition analysis of Italian energy consumption. Energy 2012, 44, 682-691. [CrossRef]

24. Wu, Y.; Chau, K.; Lu, W.; Shen, L.; Shuai, C.; Chen, J. Decoupling relationship between economic output and carbon emission in the Chinese construction industry. Environ. Impact Assess.Rev. 2018, 71, 60-69. [CrossRef]

25. Guan, D.; Su, X.; Zhang, Q.; Peters, G.P.; Liu, Z.; Lei, Y. The socioeconomic drivers of China's primary $\mathrm{PM}_{2.5}$ emissions. Environ. Res. 2014, 9, 024010. [CrossRef]

26. Yang, X.; Wang, S.; Zhang, W.; Li, J.; Zhou, Y. Impacts of energy consumption, energy structure, and treatment technology on $\mathrm{SO}_{2}$ emissions: A multi-scale LMDI decomposition analysis in China. Appl. Energy 2016, 184, 714-726. [CrossRef] 
27. Chang, M.; Zheng, J.; Inoue, Y.; Tian, X.; Chen, Q.; Gan, T. Comparative analysis on the socioeconomic drivers of industrial air-pollutant emissions between Japan and China: Insights for the further-abatement period based on the LMDI method. J. Clean. Prod. 2018, 1189, 240-250. [CrossRef]

28. Lyu, W.; Li, Y.; Guan, D.; Zhao, H.; Zhang, Q.; Liu, Z. Driving forces of Chinese primary air pollution emissions: An index decomposition analysis. J. Clean. Prod. 2016, 133, 136-144. [CrossRef]

29. Xie, Y.; Dai, H.; Dong, H.; Hanaoka, T.; Masui, T. Economic impacts from $\mathrm{PM}_{2.5}$ pollution-related health effects in China: A provincial-level analysis. Environ. Sci. Technol. 2016, 50, 4836-4843. [CrossRef]

30. Zhang, Y.; Shuai, C.; Bian, J.; Chen, X.; Wu, Y.; Shen, L. Socioeconomic factors of $\mathrm{PM}_{2.5}$ concentrations in 152 Chinese cities: Decomposition analysis using LMDI. J. Clean. Prod. 2019, 218, 96-107. [CrossRef]

31. Hoekstra, R.; Van Den Bergh, J.C.J.M. Comparing structural decomposition analysis and index. Energy Econ. 2003, 25, 39-64. [CrossRef]

32. Su, B.; Ang, B.W. Structural decomposition analysis applied to energy and emissions: Some methodological developments. Energy Econ. 2012, 34, 177-188. [CrossRef]

33. Ang, B.W. LMDI decomposition approach: A guide for implementation. Energy Policy 2015, 86, $233-238$. [CrossRef]

34. Wang, H.; Ang, B.W.; Su, B. Multiplicative structural decomposition analysis of energy and emission intensities: Some methodological issues. Energy 2017, 123, 47-63. [CrossRef]

35. Dietzenbacher, E.; Hoen, A.; Los, B. Labor productivity in Western Europe 1975-1985: An intercountry, interindustry analysis. J.Reg.Sci. 2000, 40, 425-452. [CrossRef]

36. Rose, A.; Chen, C.Y. Source of change in energy use in the US economy, 1972-1982: A structural decomposition analysis. Resour. Energy Econ. 1991, 13, 1-21. [CrossRef]

37. Cansino, M.J.; Roman, R.; Ordonez, M. Main drivers of changes in $\mathrm{CO}_{2}$ emissions in the Spanish economy: A structural decomposition analysis. Energy Policy 2016, 89, 150-159. [CrossRef]

38. Yamakawa, A.; Peters, G.P. Structural decomposition analysis of greenhouse gas emissions in Norway 1990-2002. Econ. Syst. Res. 2011, 23, 303-318. [CrossRef]

39. Ang, B.W.; Zhang, F.Q. A survey of index decomposition analysis in energy and environmental studies. Energy 2000, 25, 1149-1176. [CrossRef]

40. Bhattacharyya, S.C.; Ussanarassame, A. Decomposition of energy and $\mathrm{CO}_{2}$ intensities of Thai industry between 1981 and 2000. Energy Econ. 2004, 26, 765-781. [CrossRef]

41. Hammond, G.P.; Norman, J.B. Decomposition analysis of energy-related carbon emissions from UK manufacturing. Energy 2012, 41, 220-227. [CrossRef]

42. Enkhtsolmon, O.; Matsumoto, T.; Tseveen, E. Cost benefit analysis of air pollution abatement options in the Ger Area, Ulaanbaatar, and health benefits using contingent valuation. IJESD 2016, 7, 330-334. [CrossRef]

43. Lim, M.; Myagmarchuluun, S.; Ban, H.; Hwang, Y.; Ochir, C.; Lodoisamba, D.; Lee, K. Characteristics of indoor $\mathrm{PM}_{2.5}$ concentrations in gers using coal stoves in Ulaanbaatar, Mongolia. Int. J. Environ. Res. Public Health 2018, 15, 2524. [CrossRef] [PubMed]

44. Ang, B.W. Decomposition analysis for policymaking in energy: Which is the preferred method? Energy Policy 2004, 32, 1131-1139. [CrossRef]

45. Gao, Z.; Geng, Y.; Wu, R.; Chen, W.; Tian, X. Analysis of energy-related $\mathrm{CO}_{2}$ emissions in China's pharmaceutical industry and its driving forces. J. Clean. Prod. 2019, 223, 94-108. [CrossRef]

46. Ang, B.W. The LMDI approach to decomposition analysis: A Practical Guide. Energy Policy 2005, 33, 867-871. [CrossRef]

47. World Energy Balances. Total Final Consumption by Source, Mongolia 1990-2019. 2019. Available online: https://www.iea.org/data-and-statistics?country=MONGOLIA\&fuel=Energy\%20consumption\& indicator=Total\%20final\%20consumption\%20(TFC)\%20by\%20source (accessed on 19 July 2019).

48. World Bank National Accounts Data. GDP (current US\$)-Mongolia. 2018. Available online: https: //data.worldbank.org/indicator/NY.GDP.MKTP.CD?locations=MN (accessed on 23 December 2019).

49. Statistic Department of Ulaanbaatar. Population by Khoroo. 2018. Available online: http://ubstat.mn/ JobTables.aspx (accessed on 23 March 2019).

50. Sharma, N. The Decoupling of GDP and Energy Growth: A CEO Guide 2019. Available online: https://www.mckinsey.com/industries/electric-power-and-natural-gas/our-insights/the-decouplingof-gdp-and-energy-growth-a-ceo-guide (accessed on 9 December 2019). 
51. National Statistical Information Service, Ulaanbaatar, Mongolia. Population Growth. 2018. Available online: http://www.1212.mn/stat.aspx?LIST_ID=976_L03 (accessed on 23 January 2019).

52. Green Development Strategic Action Plan for Ulaanbaatar. British Embassy Ulaanbaatar and The Asia Foundation. 2020. Available online: https://asiafoundation.org/resources/pdfs/GreenDevelopment\% 20StrategicActionPlanforUlaanbaatar2020.pdf (accessed on 10 January 2020).

53. Urban Air Pollution Analysis for Ulaanbaatar, Mongolia. 2008. Available online: https://papers.ssrn.com/ sol3/papers.cfm?abstract_id=1288328 (accessed on 19 March 2020).

54. Cousins, S. Bulletin of the World Health Organization. Air Pollution in Mongolia. 2008. Available online: https://www.who.int/bulletin/volumes/97/2/19-020219/en/ (accessed on 10 January 2020).

55. International Energy Agency. Renewables Share in Final Energy Consumption (SDG 7.2) in Mongolia. 2016. Available online: https://www.iea.org/data-and-statistics?country=MONGOLIA\&fuel=Renewables $\%$ 20and $\% 20$ waste\&indicator $=$ Renewable $\% 20$ share $\% 20$ in $\% 20$ final $\% 20$ energy $\% 20$ consumption $\% 20($ SDG $\%$ 207.2)\%20 (accessed on 23 May 2019).

56. Geng, Y.; Sarkis, J.; Wang, X.B.; Zhao, H.Y.; Zhong, Y.G. Regional application of ground source heat pump in China: A case of Shenyang. Renew. Sustain. Energ. Rev. 2013, 18, 95-102. [CrossRef]

(C) 2020 by the authors. Licensee MDPI, Basel, Switzerland. This article is an open access article distributed under the terms and conditions of the Creative Commons Attribution (CC BY) license (http://creativecommons.org/licenses/by/4.0/). 